\title{
Tıp Eğitiminde İnsani Boyut ve Anlatı Tıbbının İmkânları
}

\section{Humanities in Medical Education and The Potentiality of Narrative Medicine}

Merve Yildiz' (ORCID ID: 0000-0002-2518-6230)

Mehmet Ali Gülpınar² (ORCID ID: 0000-0003-1765-3529)

${ }^{1}$ Doktora Öğrencisi, Marmara Üniversitesi Sağlık Bilimleri Enstitüsü Tıp Eğitimi Anabilim Dalı

${ }^{2}$ Öğretim Üyesi, Marmara Üniversitesi Tıp Fakültesi Tıp Eğitimi Anabilim Dalı

\begin{abstract}
Anahtar Sözcükler:
Biyomedikal Yaklaşım,

Tıpta İnsan Bilimleri, Tıp

ve Edebiyat, Anlatı T1bbı,

Anlatı Yeterliği

Keywords:

Biyomedical Approach,

Medical Humanities,

Medicine and Literature,

Narrative Medicine,

Narrative Competency

Gönderilme Tarihi

Submitted:24.05.2019

Kabul Tarihi

Accepted: 03.10.2019
\end{abstract}

\section{ÖZET:}

Flexner raporu, biyomedikal görüşün tıp eğitimine yerleşmesi açısından dönüm noktası olur. Flexner sonrası dönemde tıp eğitiminde biyomedikal yaklaşım güçlenir ancak sağlık eğitiminde ve sağlık bakım süreçlerinde insani ve sosyokültürel yön kaybedilir. İnsan ve hasta bireyler biyolojik ve hatta moleküler düzeye indirgenir. İnsanların aynı zamanda anlam odaklı hayat yaşadıkları gözden kaçırılır.

Zaman içerisinde "bütünlüğün kaybı" olarak değerlendirilen biyomedikal görüşe karşı anlamlı bir direnç ortaya çıkmaya başlar. Yalnızca hastaların bedenlerini değil aynı zamanda onların psişik yaşamlarını ve sosyal bağlamlarını da dikkate alan bütüncül bir yaklaşım olan "biyopsikososyal perspektif" savunulur. Tip akademisyenleri, yorumlayıcı paradigma çerçevesinde sosyal ve insani bilimlerin sağlık hizmetlerinde oynayabileceği role dikkat çekerler. Sosyal ve insani bilimlerin tıp eğitimi programlarına entegrasyonu süreç içerisinde hız kazanır ve tıp eğitiminde "tıpta insan bilimleri" bu bağlamsal zeminde gelişir. Tıpta insan bilimleri içerisinde yer alan tıp ve edebiyat çalışmaları, biyopsikososyal yaklaşımla birlikte, doktor-hasta anlatı etkileşimi dâhil olmak üzere, kişilerarası deneyimlerin devreye girmesiyle anlatı tıbbını ortaya çıkarır. Dolayısıyla anlatı tıbbı, tıp eğitiminde biyomedikal perspektifin göZ ardı ettiği insanı bütün olarak değerlendirme yaklaşımına karşı tıpta insan bilimlerinin tıp eğitimine entegre edilmesi çalışmalarının bir sonucu olarak gelişir. Tıp ve edebiyat bağlamında anlatı tıbbı, edebiyatın sanatsal söyleminin tıp eğitimine yedirilmesi amacını güder. Hastalık hikâyelerini tanıma, özümseme, yorumlama kapasitesi olarak tanımlanan anlatı tıbbı, tıp eğitiminde bütünlüğün kaybının iyileştirilmesi imkânı doğurur. Yakın/derinlikli okuma ve anlatısal/ reflektif yazım gibi eğitim etkinlikleri ile kazanılan anlatı yeterlikleri, insani duyarlılı̆̆ artmış daha nitelikli hekimler yetişmesine katkı sağlayabilir. 
$\mathrm{Bu}$ yazıda, tıp ve tıp eğitimi süreçlerine daha insani bir çerçeve sağlanması noktasında anlatı tıbbının imkânları nelerdir sorusu ele alınmış; yurtdışı ve yurtiçi çalışmalarla anlatı tıbbı uygulamalarının tıp eğitimine katkıları değerlendirilmiştir.

\section{ABSTRACT:}

Flexner report is the turning point in terms of establishing of biomedical perspective in medical education. Biomedical perspective in medical education gains power during the term after Flexner but humanistic and socio-cultural aspects in health education and health care processes are lost. Human and ill individuals are reduced to biological and even molecular level. That people also live a meaning focused life is neglected. Over time, a meaningful resistance against biomedical perspective regarded as "integration-loss" begins to appear. An integrated/biopsychosocial approach, which not only cares for patients' bodies but also psychic lives and social context is supported. Academicians draw attention to the role that social and humanistic sciences play in terms of hermeneutics paradigm. The integration of social and humanistic sciences into medical education programs accelerates over time and "human in medicine" education develops on this contextual ground. Medicine and literature studies, together with biopsychosocial approach, which are among human in medicine make narrative medicine appear with the engagement of interpersonal experiences including doctorpatient narrative interaction. As a consequence of holistic/humanistic approach, narrative medicine develops as a result of the efforts to integrate humanities into medical education against the reductionist approach of the biomedical perspective. Narrative medicine, in the context of medicine and literature, aims to embed the artistic discourse of literature in medical education. The narrative medicine, which is defined as the capacity of recognizing, internalizing and interpreting narratives of disease, gives the possibility of improving the loss of integrity in medical education. Narrative competencies gained with learning activities like close reading and narrative writing can contribute to raise more qualified doctors whose humanistic awareness has increased.

In this study, the question "what are the potentialities of narrative medicine?" has been dealt with in terms of providing a more humanistic framework into medicine and medical education; the contributions of narrative medicine educational activities have been evaluated by means of domestic and abroad studies.

\section{Tıp Eğitiminde Biyomedikal Perspektif ve Bütünlüğün Kaybı}

Flexner'in 1910 tarihli raporu, tıp eğitiminde biyomedikal perspektifin yerleşmesi açısından dönüm noktası olur. Bu raporla birlikte sağlık eğitiminde ve sağlık bakım hizmetlerinde süreç içerisinde biyomedikal perspektif baskın olmaya başlar. İnsan ve hasta bireyler, vücutlara, organlara ve dokulara, hatta son zamanlarda moleküler düzeye indirgenir. İnsanın aynı zamanda anlam odaklı hayat yaşadığı gözlerden kaçırılmaya başlanır. Flexner sonrası dönemde tıp eğitiminde biyomedikal yaklaşım güçlenir ancak sağlık süreçlerinde insani yön kaybedilir $(1,2)$. Bu süreç, bugün için, her biri sağlık bakım ve eğitim süreçlerinin önünde çözüm bekleyen sorun alanları olarak duran bir dizi önemli problem alanını beraberinde getirir:

.... aşırı uzmanlık; teknikalizm; aşırı profesyonelleşme; kişisel ve sosyokültürel değerlere duyarsızlık; doktorun rolünün çok daraltılması; "önemsemek" yerine "çok fazla“ ilaç”; hastalığı önleme, hasta katılımı ve hasta eğitimi ile ilgili yetersiz vurgu; çok 
fazla ekonomik teşvik; bir "ticaret okulu" zihniyeti; gündelik hayatta aşırı beslenme; tıp öğrencilerinin biyomedikal bakış açısı; ev halkının aşırı çalışması; sözel ve sözel olmayan iletişimdeki eksiklikler... (3).

Dile getirilen bu sorun listesi, bir yönüyle sağlık bakım ve eğitim süreçlerinde insani yönün kaybı olarak çerçevelendirilebilir. Tıp eğitimi yavaş yavaş bir çeşit "uygulamalı biyoloji" haline geldi diyen bir araştırmacı, tıbbi bir dergiden tipik bir olgu sunumunu bu duruma örnek gösterir:

22 yaşında sağlıklı, sigara içmeyen bir adam, bir fincan parlak kırmızı kan öksürdü. İlk öykü ve fizik muayenede tanı konulamadı. Akciğer filmi, arteryel kan gazı seviyeleri, tam kan sayımı, koagülasyon indeksleri, trombosit sayısı ve kan üre nitrojen konsantrasyonu normal...(4).

$\mathrm{Bu}$ olgu sunumuna fenomenoloji (anlambilim) perspektifinden bakıldığında; "bu adamın kim olduğu, nerede olduğu, ne yaptığı, hastaneye nasıl gittiği, hastalığı ile ilgili duyguları vb. konularda hiçbir bilgi verilmemiştir. Tam da bu noktada sorulması gereken sorulardan bir kısmı şunlardır: Aynı zamanda bir insan olan hastanın bu şekilde sunulması nasıl gerçekleşti? Biyomedikal perspektif hastalıkların sebeplerini ne kadar tahmin edebilir, sağlık ve hastalık süreçleri ne kadar etkin yönetilebilir veya hasta bir birey olarak kendi biricikliği içinde ne kadar anlaşılabilir? Sağlığı ve hastalığı anlamak ve bu süreçleri etkin bir şekilde yönetebilmek için, biyomedikal perspektifin ve mekanikliğin ötesinde farklı bir perspektife, insanın bütünlüğüne ve bilincine dönülmelidir (1).

\section{Sosyal ve İnsani Bilimlerin Tıp Eğitimine Katkıları}

Flexner raporu sonrasında 1950'li yıllarla birlikte bütünlük ve insani perspektif arayışları gündeme gelmeye ve 1970 ve 1980 'lerde de biyomedikal görüşe karşı anlamlı bir direnç ortaya çıkmaya başlar. Yalnızca hastaların bedenlerini değil aynı zamanda onların psişik yaşamlarını ve sosyal bağlamlarını da dikkate alan bütüncül bir yaklaşım olan, "biyopsikososyal" yaklaşım savunulur. Tip akademisyenleri, yorumlayıc1 paradigma çerçevesinde sosyal ve insani bilimlerin sağlık hizmetlerinde oynayabileceği role dikkat çekerler. Tip bilimleri, bilgi tabanlarını sosyal bilimlerin bakış açılarından sorgulamaya başlar (1). Tıp alanı sadece doğa/ fen bilimlerini temel almaz, aynı zamanda ilişkisel ve toplumsal bir temelde uygulamalarını gerçekleştirir. Benzer şekilde "hastalık, özünde, biyolojik ve maddesel bir olgu olsa da, insanın ona tepkisi ne biyolojik ne de aritmetik olarak belirlenir" (5). Hatta daha da ileri gidilerek sağlığın ve hastalığın özünde sadece biyolojik süreçler olduğu görüşü dahi tartışmaya açılır. Daha ilişkisel/karmaşık bir yaklaşımla sağlık ve hastalık biyolojik, davranışsal, sosyokültürel vb etkileşimler çerçevesinde ele alınmaya başlar. Tıp, hasta ile hekim arasında özel bir etkileşimsel ilişki gerektirdiğinden tıp pratiğinin hastalarla günlük karşılaşmaları sırasında öncelikle biyolojik perspektiften değil otantik bir ilişki penceresinden bakılması gerektiği savunulur. $\mathrm{Bu}$ bağlamsal zeminde sosyal ve insani bilimlerin tıp eğitimi programlarına entegrasyonu süreç içerisinde hız kazanır ve tıp eğitiminde insan bilimleri tıpta insan bilimleri (medical humanities) ile kendine yer bulmaya başlar.

Tıpta insan bilimleri, "insan hayatının tüm karmaşıklığını, farklılığını ve belirsizliğini, çok geniş bir tuvale çizilmiş resim olarak görme sanatı" olarak tanımlanır (6). Tıp; insanı sağlık ve hastalık bağlamında anlama san $\neg$ atı olarak görülmeye başlanır. Nitelikli hekimlerin yetişebilmesi adına biyopsikososyal model esas alınarak biyomedikal perspektif kadar insani 
ve sosyokültürel perspektifi de içselleştirmiş, sağlık ve hastalık süreçlerini aynı zamanda insani ve sosyokültürel duyarlılıkla ele alan ve yönetebilen mezunların yetişmesi hedeflenir.

Tıp eğitimi programlarına tıpta insan bilimlerinin sağlam bir şekilde entegre edilmesi, eğitim sürecinin tüm dönemlerine yedirilmesi tıp eğitimine şu dört değerli katkıyı sağlar (7).

1. Kanıta dayalı tıpla ilişkili bilgi sağlamada, tutarlı, mantıklı, araştırma liderliği ruhu ile ifade edilen, şüpheci ve eleştirel bakabilmeyi arttırır.

2. Programa yedirilen tıpta insan bilimleriyle, klinik süreçlere etik bir boyut eklenir. Klinik karar verme ve değerlendirme yeterlikleri etik nedenselleştirme, etik karar verme ve değerlendirme yeterlikleri ile daha bütüncül ve nitelikli bir hale kavuşur.

3. Klinik akıl yürütme sürecine eklenen hastaların öykülerine karşı duyarlılık ve anlatı ile ilgili yeterlikler ve değerler ile klinik süreçlerde insani bir farkındalık yaratılır.

4. Profesyonelliğine ilişkin yeterliliklerden, empati, belirsizlik ve karmaşıklıkla baş edebilme, bütüncül yaklaşım, estetik ve etik yeterlikler gibi kazanımlar güçlendirilir.

Özetle tıpta insan bilimleri, tıbbın aynı zamanda bir sanat olduğunu yeniden hatırlatarak geleneksel bilim paradigmasının hiyerarşik, kutuplaştırıcı, katı disipliner bakış açısını sorgulatır ve de yumuşatmaya çalışır.

\section{Tıp ve Edebiyat Bağlamında Anlatı Tıbbı}

Anlatı tıbbı gerçekten bir devrim mi? Yoksa bu bir sapma mi, tıp mesleğinin sınırları çerçevesinde sadece birkaç kişinin paylaştığı bir şey midir? - Myrth-Kaplan, 2007
Anlatı tıbb1 (Narrative Medicine), tıpta insan bilimlerinin tıbba yeniden insani bir perspektif kazandırmaya yönelik çabaları sonucu, özellikle edebiyatın sanatsal/estetik duyarlılığının tıp eğitimine yedirilmesi amacı güden bir zeminde doğar. İlk olarak 2000 yılında Rita Charon tarafindan kullanılan anlatı tıbbı, hasta ve hastalık hikâyeleri üzerinden hasta bireyin ve hastalık sürecinin, sağlık/hastalık bakım sürecinin daha derinlikli anlaşılma, tanınma, özümsenme, yorumlanma ve yönetilme/koordine edilme kapasitesi olarak tanımlanabilir. Anlatı tıbb1 ayrıca, tıbbın edebiyat, şiir, kısa öykü, roman ve etnografya üzerinden ele alınma çabasını da kapsar. Tıp eğitiminin bir parçası olarak edebi eserler ve çalışmalar tıp pratiğinin iyileştirilmesi imkânı doğurur (8). Anlatı tıbbı, tıpta insan bilimlerinin kavramlarını kullanarak öğrencileri ve hekimleri hastalarının öykülerini okuma, öykülerine kulak verme ve bununla hastalarının hayatlarına dokunma yönünde hazırlar. Okuma eylemi gibi edebiyatın bir bileşeni olan yazma eylemi de öğrencilere ve klinisyenlere hastalarının hastalık deneyimlerinin yanı sıra kendi kişisel ve duygusal tepkilerini ele alma ve deneyimlenen klinik süreçleri daha yakından ve ayrıntılı olarak inceleme firsatı tanır. Okuma ve yazma eylemleri klinisyenlerin duyguları işleme kapasitesini geliştirir ve anlatı temsili ile öz-refleksiyon becerilerini artırarak yaşam öykülerinin açığa çıkmasına aracılık eder. Dolayısıyla anlatı tıbb1, kendi bütünlüğü/ biricikliği içinde ele aldığı sağlık ve hastalıkla ile ilgili deneyimlere insani bir duyarlılık ve perspektif katarak insani ve sosyokültürel duyarlılı̆̆1 yüksek hekimler yetişmesine katk1 sağlar (1).

Anlatı tıbbı, bir doktorun eğitiminde veya eğitim programlarında sadece bir süsleme veya hoşluk olarak görülmemelidir. Daha nitelikli bir tıp eğitimi ve mezunlar için, insani ve sosyokültürel 
duyarlılığı daha yüksek sağlık bakım süreçleri için, tıp pratiğinde yer etmesi gereken temel disiplinlerden birisidir (9). Tibbi uygulamalar için bir model olarak ele alınabilecek anlatı tıbbı, nitelikli sağlık bakımına yönelik bir ideal önermekte (insani, duygusal ve sosyokültürel açıdan duyarlı sağlık bakım süreci) ve bu ideale doğru çaba göstermek için kavramsal çerçeve, anlatısal yeterlikler ve pratik araçlar/ eğitim etkinleri sunmaktadır. Yakın/derinlikli okuma (close reading), incelikli/özenli dinleme (attentive listening), sıkıntıya/acıya eşlik etme (bearing witness to suffering) ve anlatisal/ reflektif yazım (narrative/reflective writing) gibi anlatısal eğitim tekniklerinin kullanıldığı, tıp ve edebiyat temelli eğitim uygulamalarıyla anlatı tıbbı şu üç ana kavramsal çerçeve ve aşama üzerinden temellenir: “dikkat/özen/yönelim (attention)", “temsil/betimleme/simgeleme (representation)" ve "bağlanma/yakınlık (affiliation)" (9, 10, 11).

Anlatı tıbbında sağlık bakım süreci dikkat aşaması ile başlar. Bu aşamada hekim, hasta bireyin o andaki varoluşuna/hastalığını deneyimleme biçimine kapı aralamaya, hasta bireyi ve içinde bulunduğu durumu/bağlamı anlamaya odaklanır. Hastanın deneyimini kendi biricikliği içinde anlamaya çalışır. Hekim hastanın sözlerinden, sessizliğinden, hareketlerinden, fiziksel görünüm ve durumundan sızan ipuçlarına dikkat ederek, bunları not ederek hastanın ne anlatmak istediğini derinlikli bir şekilde anlama çabası içine girer. Yargısız bir farkındalık ile hekimi, hasta bireyi etkin bir şekilde dinlemeye ve hastanın hastalığına ilişkin deneyimini kendi biricikliği içinde derinlikli bir şekilde anlamaya açar.

Temsil aşamasında hekimin, hastanın ve hasta yakınının nesir, şiir, öykü, anı, günlük vb. anlatısal yazımlarıyla (narrative writing), karmaşık, kaotik, biçimsiz ve belirsiz/bulanık olan klinik durumlar ve hastalığa/sağlık bakım süreçlerine ilişkin deneyimler, bu yazım sürecinde ortaya çıkan temsiller, betimleme biçimleri, ifade ediliş şekilleri, işaretler, simgeler, semboller, benzetimler vb. ile taraflar için daha bir duyulabilir, hissedilebilir durumlara, daha bir görünür durumlara bürünür. Anlatısal yazım ve okuma etkinlikleri, anlatısal refleksiyonlarla hekimin ve hastanın kendi başlarına yaşadıkları görece yalnız iki deneyimin kapılarını birbirine aralar ve bu yalnız deneyimler karşılıklı olarak daha bir paylaşılır hale gelir. Bu süreç üçüncü aşamada hekim ve hasta arasındaki tanışıklığı, yakın ilişkiyi ve yakınlaşmayı beraberinde getirir. Bir diğer ifadeyle, anlatısal yazımla hasta daha bir "görünür" olur; hekim hastasını, hastasının acısını "duyar/hisseder" ve hastasına, hastasının durumuna daha açık hale gelir. Hekim ile hasta arasındaki etkileşim derinlik kazanır, insanileşir. Yazım eylemi öncesinde, süreci tek başlarına kendi içlerinde yaşayan, kendi dertlerine, acılarına ve meselelerine gömülü hekim ve hasta iki ayrı varlık iken; anlatısal yazım ve anlatısal refleksiyonla, bir sonraki aşamada taraflar için birbirlerini anlayan, tanıyan, tanışıklık oluşturan bir yakınlaşma, paylaşım ve birliktelik umudu doğar.

Dikkat ve temsil aşaması birlikte anlatı tıbbının üçüncü aşaması olan ve anlatı tıbbının nihai hedefi olan "yakınlığı/yakınlaşmayı" beraberinde getirir. Hasta ve hekim arasındaki kopukluk karşılıklı "bağlanma”ya dönüşür. Hekim ve hasta arasında, hemşire ve sosyal hizmet uzmanı arasında, ölmekte olan bir ebeveyn arasında ve adil bir sağlık hizmeti bekleyen biri arasında sahici ve güçlü ilişkilenmeler, paylaşımlar ortaya çıkar. Tarafları birbirlerinin gündemlerini, meselelerini paylaşmaya, birbirinin deneyimine eşlik etmeye, birini diğerinin acısına ortak olmaya doğru kapı açar. Taraflar ve deneyimleri 
iç içe geçer. Aynı zamanda yaşanan deneyim üzerinden, kendi deneyimi ve muhatabının deneyimi üzerinden, her bir kişiyi kendine açar, kendi ile ilişkilenmesine, kendi ile yeniden tanışıklık/yakınlık kurmasına firsat tanır.

Özetle, anlatı tıbbında "dikkat", bir insanın diğerine hazır ve açık olması, özenle yönelmesi durumudur. Kişinin kendi bakış açısının ve dikkatinin ötesine geçerek diğerinin yaşamına ve ihtiyacına odaklanması, dokunmasıdır. $\mathrm{Bu}, \quad$ yakın/derinlikli okumada okuyucunun öyküler aracılığıyla diğerinin anlatı dünyasına, hikâyesine girmesi için gösterdiği çabaya benzer. Böylece o deneyimi yaşayanlarla, o anlatılarda yer alan anlamların peşinden gidilir. Edebiyattan ödünç alınan bu teknikle, tıp eğitiminde yakın okuma eğitimi ile hekim adaylarında daha insani özenler/ dikkatler oluşturabilir. Öğrencilerin karmaşık klinik durumları ve deneyimleri kelimelerle temsil etmeleri istendiğinde görece biçimsiz, şekilsiz, belirsiz ve puslu durumlar daha bir netleşebilir, şekil kazanabilir, kendinde ve muhatabında yeniden hayat bulabilir. Hasta ve hastalık sürecine ait kısa bir hikâye, bir şiir, kaybın arkasından yazılan birkaç cümle, kelimelere dökülen bir anı, bir duygu, bir aşk hikâyesi okunduğunda yaşanan yalnız deneyimler herkes için daha bir görünür kılınabilir. Bir metinin derinlikli okuması, kişilere kendi durumları ve muhatabının içinde bulunduğu durumları daha derinlikli ve katmanlı bir şekilde anlama imkânı sunabilir. Bir hekim adayı veya hekim için, hastasını içinde bulunduğu durumla birlikte daha derinlikli anlama, hastasıyla ve hastası üzerinden kendisiyle daha sahici ve sicak ilişkilenme imkânı anlamına gelebilir. Dikkatle alınan/düşülen notlar ve temsillerin mümkün kıldığ1 karşılıklı tanışmalarla derinleşen bir ilişki, sağlam bir klinik ilişkilenmeye ve yakınlık kurmaya yol açabilir. Nihayetinde üç aşamalı bu tür bir anlatısal ilişkilenme insani ve sosyokültürel açıdan daha nitelikli bir sağlık/ hastalık bakım sürecini beraberinde getirebilir (11).

\subsection{Anlatı Tıbbının Önemi ve Etkileri}

Ontolojik düzeyde "incinmiş/yaralı insanlık" (wounded humanity) olarak kavramsallaştırılan hasta bireyin incinmiş insanlık durumu; bedensel engellilik nedeniyle eylem özgürlüğünü kaybetmesi, iyileşmeye doğru rasyonel adımlar atmak için gerekli bilgiye sahip olmaması ve bir dereceye kadar özerkliğini kaybetmesi, başkalarına bağımlılı̆̆ının artması gibi durumlarla açıklanır. Hastanın bu durumu, klinik karşılaşmada ikincil olmaktan ziyade, iyileşme ilişkisinin temeli olarak görülmelidir. Eğer şifa, "hastalık deneyiminin yarattığı kusurları gidermeyi amaçlayan karşılıklı bir eylem" ise hekimin iyileşme ilişkisine girmesinin tek yolu, yaralı insanlığın anlaşılmasından geçecektir (12).

Anlatı tıbbına duyulan ihtiyaç "yaralı insanlık" bağlamında, biyopsikososyal yaklaşımla birlikte, doktor-hasta anlatı etkileşimi dâhil olmak üzere, kişilerarası deneyimlerin devreye girmesiyle ortaya çıkar. Anlatı, hastanın beklentisi için anlam, bağlam ve bakış açısı sunar. Hastanın, nasıl, neden ve ne şekilde hastalandığını tanımlayabilmenin ötesinde, anlatı çalışması, başka herhangi bir yoldan ulaşılamayacak bir anlayış geliştirmeye olanak sağlar. Bu noktada klinik yeterlilik hem biyomedikal hem de anlatısal yeterlilikleri içerir. Hekimi hastadan, kendinden, meslektaşlarından ve toplumdan ayıran bölünmeleri ortadan kaldıracak olan anlatı tıbbı hekimlerin hastalarına özenli, otantik ve etkili bir bakım sunmasına yardımcı olabilir. Anlatısal yeterlikler hastanın anlatımlarını dinleme, anlama, değer verme ve hasta adina hareket etme becerileridir. 
Bunlar hekimlerin hastalarının hikâyelerini özümsemek, yorumlamak ve karşılık vermek için kullanacakları yeterliliktir (13).

Anlatı tıbbının taraflar üzerinde dönüşümsel etkileri vardır. Bir tür doğaçlama olarak görülebilecek olan anlatı ve anlatı tıbbı, hekim ve hasta arasında, bunları çevreleyen çevresel ve sosyokültürel yapılara meydan okumaya yönelik aktif bir girişime, anlam adına ilerlemeyi engelleyen etkenlerin ötesine geçmeye imkân tanır (14). Klinik süreçlerde hastaların, hasta yakınlarının ve sağlık çalışanlarının anlatıları iç içe geçer, birbirini etkiler, dönüştürür ve yeni anlamlar yaratır. $\mathrm{Bu}$ dönüşüm, yorumlanmış, bir şeye dönüştürülmüş hikâye üzerinden gerçekleşir (hasta ve hekim arasında gerçekleşen diyalog yoluyla oluşan yap1 ve anlam). Anlatısallık (Narrativizasyon) bu nedenle hastalığa yakalanmış insanlar için reflektif, terapötik ve hatta dönüştürücü bir mekanizma olarak işlev görür. Hasta hekimin çalışma sahasına girdiği an itibariyle, hekim de bu hikâyenin bir parçası olur (15).

\subsection{Anlatı Tıbbı İle İlgili Yeterlikler}

Bir insanın diğerine yardım ettiği bir meslek olarak tıp, her zaman yaşamın öznelerarası alanında var olagelmiş ve içinde bir anlatı ile birlikte anlatı kaygısı taşımıştır. Hem anlatım hem de sağlık uygulamaları bir kişinin diğeriyle etkileşimini gerektirir. $\mathrm{Bu}$ etkileşim otantik bağlamın tüm katılımcılar için dönüştürücü olduğu bir sahadadır. Anlatısal yeterlikler (narrative competencies) birer birey olan hekimlerin her biri farklı bir birey olan hastalarının ve meslektaşlarının yanı sıra topluma karşı da görevlerini nitelikli bir şekilde yerine getirebilmesi için sahip olması gereken yeterlikler arasındadır (13).

Anlatısal yeterlikler metinsel beceriler (öykünün yapısının anlaşılması, çoklu perspektiflerin metaforların, imaların, kinayelerin tanınması), yaratıcı beceriler (çoklu yorumların, yaşam örgülerinin oluşturulması ve hayal edilmesi, merak duygusunun oluşturulması, çoklu sonların/bitişlerin kurgulanması) ve duyuşsal becerilerin (belirsizliğin kucaklanması/tolere edilmesi, anlatının duygusuna girilmesi) kombinasyonlarını gerektirir. Anlatısal yeterlik aynı zamanda anlatan ve dinleyen/duyan arasındaki etik karmaşıklığın ve anlatının etik boyutun farkında olmayı da içerir (9).

Metnin devamında anlatısal yeterlikler, beraberinde getirdiği dönüşümlerle birlikte ele alınmıştır. Tıp eğitimi sürecinde anlatı tıbbı etkinlikleri kapsamında kazanılacak bu yeterlikler, mezunun sadece biyomedikal açıdan değil aynı zamanda insani ve sosyokültürel açıdan da duyarlı ve nitelikli bir sağlık bakım hizmeti sunabilmesi için gerekli olan yeterliklerdir.

\subsubsection{Empatik yakınlı (Empatik engagement)}

Empati, hekimin hastanın perspektifine girdiği bilişsel süreç, hekimin kendini hastanın yerine koyduğu duygusal süreç ve hekimin hastayla etkileşimini yeniden kontrol ederek anlaştığ1 eylem süreci olarak üç farklı bileşenden oluşur. Hasta hekimle buluştuğunda, bir konuşma başlar. Hikâye, bir dizi olay anlatımı, sözler, jestler, mimikler ve sessizliklerle anlatılan karmaşık bir hasta anlatımının ortaya çıkmasıyla sonuçlanır. $\mathrm{Bu}$ hikâye, hastalık hakkında nesnel bilgilerin yanında, korkular, umutlar ve duygularla ilişkili anlamlandırmaları da içerir. Anlatılan olaylar vasitasıyla hastanın anlatı dünyasına girilir (16). Hastalık öykülerinin dinlenmesi hekime, terapötik bir ilişki, ayırıcı tanı koyma ve sürdürme, fiziksel bulguları 
ve laboratuvar raporlarını doğru bir şekilde yorumlama, hastaya empati ile yaklaşma becerisinin yanında, etkili bir sağlık bakımı elde etmek için de firsat sağlar. Konuşma için mevcut zamanı kısaltan ve klinik ilişkilerin sürekliliğini sınırlandıran dış etkenlere rağmen anlatı tıbbı, hikâyeleri anlatmanın ve onlara kulak vermenin öneminin 1srarla altını çizer. Anlatı becerileri, hekimlerin hastalarıyla etkin katılımla empatik ilişkiler kurmasına yardımcı olacak yöntemler sağlayabilir (13).

\subsubsection{Hekimin kendi uygulamalarının refleksiyonu (reflection in practice)}

Hekimler, hastalarıyla sahici bir bağ kurarak, insani durumu kabullenme, çekilen sıkıntıya/ acıya aşina olma ve bağışlama kapasitelerini geliştirebilirler. Hekimin en güçlü terapötik aracı kendisidir ve hekim kendisini hastanın yaşadığı deneyimin ve sağlık bakım sürecinin refleksiyonu üzerinden bulur/tanır ve bununla hastasına ve hastasının durumuna daha açık hale gelir. Birer reflektif uygulayıcılar olarak hekimler, deneyim sırasinda kendi duygusal tepkilerini tanımlayarak, yorumlayarak ve yaşanan deneyimleri anlamlandırarak hem kendileri hem de hastalarıyla yüz yüze gelirler (17, 18). Kendi pratiği üzerinden refleksiyonla hekim hem hastasının durumu, hem kendi durumu hem de hekimlik pratiğinin içinde gerçekleştiği bağlam ile ilişkilenir. $\mathrm{Bu}$ etkileşim hekimin hem kendisi hem de hastası ile yakınlık kurmasına, kendini ve hastasını daha iyi anlamasına ve sağlık süreçlerini kendi bağlamlarında ele almasına, anlamasına, anlamlandırmasına ve yönetmesine/koordine etmesine imkân verir.

\subsubsection{Meslektaşlar arası yakınlık ve profesyonellik}

Hekimlerin eğitim, araştırma ve klinik hizmete ilişkin faaliyetleri ve uygulamaları anlatı çalışmalarıyla zenginleştirilebilir ve anlatısal yeterliklerle daha etkin süreçler haline dönüştürülebilir. Aynı zamanda bu süreçler sağlık çalışanlarının kendi profesyonel yeterliklerinde ve anlatisal yeterliklerinde yetkinleştikleri, profesyonel kimliklerini ve aidiyetlerini, meslektaşlar arası yakınlıklarını ve kendi işlerine olan bağlılıklarını güçlendirdikleri süreçlerdir. $\mathrm{Bu}$ süreçlerde hekim, hekimin bilgi devamlılığı için bir araç işlevi görür ve mesleki gelişim sürecinde profesyonelleşir. Mesleki yaşamları üzerinden doktorlar birbirlerinin zekâsını, birbirlerinin zaferlerini onaylama, birbirlerinin eksikliklerini, hatalarını kucaklama ve birbirlerinin üzüntülerini görme ve ortak olma gibi eylemlerle birbirleriyle ve kendileriyle tanışırlar. Hekimler arasında oluşan bağlar/ yakınlıklar birbirlerinden sorumlu, birbirlerine açık ve birbirlerini destekleyen, geliştiren bir çalışma ortamının/ikliminin ve ekibin oluşması ile sonuçlanır (13).

\subsubsection{Hekimin toplumla yakınlığı ve toplumsal güven}

Hekimler sağlık ve hastalık süreçleri üzerinden kurtarma, iyileştirme ve yönetme gibi görevleri yerine getiren önemli birer toplumsal figürdürler. Hekimlere, topluma zarar vermeden hastalıkları anlama, önleme, tedavi etme ve kontrol etme gibi yetkiler verilmiştir. Hekimlerden, bir taraftan toplumun sorunlarına ve beklentilerine karşı sorumluluklarını yerine getirmeleri beklenirken; aynı zamanda onlardan acı karşısında hassasiyet, tehlike karşısında cesaret ve ölüm karşısında rahatlatma gibi insani görevler beklenir. Hastaların, kendilerine bakım verenlerin erdem ve bilgeliğine örtük bir güvenleri vardır ve olmalıdır. Toplumsal güven hekimler ile toplum arasındaki sağlıklı ilişkilenmenin en önemli bileşenlerinden 
birisidir. Hekimler, hastalar, aileler, diğer sağlık profesyonelleri ve farklı toplumsal kesimlerle sade, dürüst ve derinden konuşmanın yollarını bulmak; şefkat, adalet ve merhamet ile görevlerini yerine getirmek durumundadırlar. Onlardan toplumla bilimsel ve rasyonel bir dil kadar anlam, değerler ve duygular üzerinden oluşturulan bir dille derinlikli bağlar kurmaları, sağlık/bakım süreçlerini insani, toplumsal ve kültürel açıdan daha duyarlı süreçlere dönüştürmeleri ve anlatısal yeterliklerle birlikte bu yönde yetkinlik geliştirmeleri beklenir (13).

\subsection{Anlatısal Yeterlikleri Geliştirmeye Yönelik Etkinlikler}

Bir hastanın hikâyesi çok şey söyler ancak, bu hikâyeyi/anlatıyı özümsemek, yorumlamak ve uygun yanıtlar oluşturmak özel bir beceri seti gerektirir. Anlatı yeterliği olarak adlandırılan bu beceriler, anlatının yapısını anlamak, çoklu perspektifleri, metaforları, imaların, kinayeleri tanımak gibi metinsel becerileri; çoklu yorumları, yaşam örgülerini oluşturma, merak duygusunun oluşturma ve çoklu sonları kurgulama gibi yaratıcı becerileri; belirsizliği kucaklama, anlatının duygusuna girme gibi duyuşsal becerileri gerektirir. Hekimler, anlatı yeterliliklerini geliştirerek, hastanın deneyimini daha iyi anlayabilir ve böylece ona yardımcı olmak için daha donanımlı olabilirler. Anlatı tıbbı, bu beceri setinin geliştirilmesine ve kullanılmasına dayanan klinik uygulama için bir çerçevedir (19).

Anlatı tıbbı yeterliğini geliştirmek için kullanılan eğitim etkinlikleri arasında yakın/ derinlikli okuma (close reading), anlatısal yazım (narrative writting) ve reflektif yazım (reflektif writting) gibi etkinlikler vardır. Literatürde anlatısal yazım ve reflektif yazım zaman zaman birbirinin yerine kullanılsa da anlatısal yazım anlatılar üzerinden ilerleyen reflektif yazımlar şeklinde anlaşılabilir.

\subsubsection{Yakın okuma}

Son yıllarda sağlı eğitimcileri tarafindan, sağlık mesleği mensuplarına dinleme becerileri ve psikolojik/duyuşsal bakış açısı kazandırmaya yönelik ciddi çabalar sarf edilmektedir. Klinisyenlerin dinleme performanslarını iyileştirmek için iletişim çalışmaları, edebiyat ve tıp, drama, sağlık psikolojisi, söylem analizi ve dilbilimi gibi birçok disiplin çerçevesinde eğitim uygulamaları yapılmaktadır. Anlatı tıbbında kullanılan yakın okuma bunlardan biridir. Yakın okuma ile sağlık profesyonelleri, görüşme, dinleme, duyguların farkında olma gibi beceriler geliştirirler (20).

T1p eğitiminde edebi metinlerin incelenmesi, öğrencilere birçok avantaj sunar ve başka bir şekilde elde edilemeyecek becerileri geliştirir. Edebiyat yoluyla, bir okur, başkalarının deneyimine girer ve bu deneyimler üzerinden kendi dünyasını aralar. Farklı perspektifler, yaşamlar, yaşanmışlıklar, karakterler, durumlar, düşünceler, davranışlar, duygulanımlar ve anlamlarla tanışıklık kurar. Hekim bir yazarın hastalık, 1stırap, acı ve ölümle ilgili anlatılarını okuyarak, anlamaya ve yorumlamaya çalışarak kendi hastasının deneyimini ve kendi sağlık pratiğini daha iyi anlamaya başlar. Hastası ve kendisi ile insani yakınlıklar kurmaya ve bu yakınlıklar üzerinden kendini ve pratiğini dönüştürmeye başlar $(19,21)$.

\subsubsection{Anlatısal/reflektif yazım}

Anlatısal yazım, öğrenenlerin eleştirel düşünmeyi geliştirmelerine, kolay varsayımlara meydan okumalarına, hastalarına ilişkin farkındalıklarını güçlendirmeye ve daha derin düşünebilmelerine, hastalarının duygularını 
daha fazla fark etmelerine yardımc1 olacak önemli bir eğitim aracıdır (22).

Anlatısal yazım, daha derin anlamayı, anlam üretmeyi ve gelecekteki davranışlara rehberlik edebilmek için deneyimlerin gözden geçirilmesini ve yorumlanmasını içerir. Bundan dolayı açıklamadan daha fazladır ve açıklamanın ötesine uzanır (23). Bir fikir vermez, spekülatif ya da soyut değildir, öznellik ve deneyime ilişkin ayrıntı bakımından zengindir. Anlatısal yazım, kesinlik içermeyen (kesin doğrular, cevaplar, çözümler), belirli bir bakış açısını zorlamayan ve çoklu yorumların ortaya çıkmasına izin veren bir etkinliktir. Amacı, eleştirel düşünme ve analizi geliştirmek, kendinin ve başkalarının duygularını daha iyi anlamak, belirsiz ve karmaşık durumlarla yaşamayı öğretmektir. Hekimler birden çok sebepten dolayı anlatısal/ reflektif yazımı kullanır. Estetik, yaratıcı amaçlara ulaşmak, kişiliklerinin diğer yönlerini ifade etmek, travmatik/rahatsız edici klinik olayları teşhis etmek ve hatta iyileştirmek, kendine ve başkalarına ait karmaşık duyguları anlamak ve işlemek bu nedenlerden bir kaçıdır. Benzer deneyimlerin paylaşılması ve kişinin akranları tarafından görülmesi ve tanınması, sağlık süreçlerinin duygusal boyutuna dair içgörü geliştirilmesi ve bununla mesleki tükenmişlik gibi durumların önüne geçilmesi akla gelen diğer nedenlerdir (22).

Reflektif yazımda genellikle hastanın bakış açısından hastanın deneyimine odaklanılır. $\mathrm{Bu}$ yazımlar, vaka raporları sunumundan farklıdır. Daha deneyimsel ve reflektif bir dil kullanılır. Bu dil hekimin empati yeteneğini arttırır, hekim ve hasta arasındaki duygusal katı mesafeyi azaltır. Daha önce göz ardı edilen, ele alınamayan, tanınmayan duyguları ortaya çıkarır. Ek olarak, anlatısal yazımda hekimin refleksiyonları aracılığıyla hastanın sesi ve anlatısına hekimin sesi ve anlatısı da eklemlenir. Hekimin kendi pratiği üzerinde düşünmesine, kişinin kendisine eleştirel bir gözle bakmasına imkân sağlar. Refleksiyonlar, bir yazar olarak hekime, hem kendi bakış açısı ve kararları hem de meslektaşlarının bakış açıları üzerinde yeniden düşünebileceği bir alan açar. Ayrıca reflektif yazım, empati, kişisel tatmin ve ilişki/yakınlık kurma gibi anlatı tıbbına ilişkin yeterliklerin ve sonuçların gelişiminde etkilidir (19).

\subsection{Anlatı Tıbbına İlişkin Eğitim Uygulamaları}

Anlatı yeterlikleri, geleneksel tıp eğitimi veren fakültelerin eğitim programlarında veya sağlık bakımı veren hastane kliniklerinin bir parçası olarak nadiren öğretilir. Bununla birlikte anlatı tıbbı, dünyadaki birçok tıp fakültesinde eğitim programlarının bileşenlerinden birisidir. Anlatı tıbbı programlarda genellikle iki şekilde yer alır: (1) sağlık ve hastalıkla ilgili edebi metinlerin okunması, başkalarının öykülerinin duyulması ve yorumlanması (2) hastanın ve profesyonelin bireysel deneyimine ilişkin anlatısal/reflektif yazım uygulamaları (19).

Tıp ve edebiyat 1970'lerin başından beri, dünyada birçok tıp fakültesinde tıpta insan bilimleri programlarının bir parçası olarak uygulanmaktadır (24). Sağlık ve İnsan Değerleri Derneği tarafından 1994 yılında yürütülen gayri resmi bir araştırmada, ABD tıp okullarının \% 30'unda, programlarının bir parçası olarak edebiyata yer verildiği saptanmıştır (25). Bu oranın 1998'e gelindiğinde \% 74'e çıtı̆̆ görülmüştür. Üstelik edebiyat ve tıp ile ilgili bu programların \% 39'unun fakültelerin eğitim programlarında zorunlu program arasında yer aldığ 1 belirtilmiştir. Bir alt disiplin olarak edebiyat ve tıp şu anda lisansüstü eğitim programları ve araştırma finansmanı kaynakları dâhil olmak üzere kendi akademik dergileri ile sağlık alanında kendine önemli bir yer 
edinmiştir (19).

\subsubsection{Eğitim uygulamalarından örnekler ve ilgili araştırmalar}

Yurtdışında anlatı tıbbı hem tıp fakültelerinin eğitim programlarında hem de hizmetiçi eğitim uygulamaları (kurslar, seminerler, atölye çalışmaları ve çeşitli eğitim stratejileri içeren anlatı tıbbı uygulama örnekleri) şeklinde kendine yer bulmuştur.

Colombia Üniversitesi Sosyal Pediatri Programı'nda “Kültürel Yeterlik ve Anlatı Tıbbı" modülü ile anlatı tıbbı yerleşik iki yıllık bloğa entegre edilmiştir. $\mathrm{Bu}$ modülde, pediatri asistanları ile hizmet verdikleri yerel halktan oluşan (özellikle de kötüye kullanım ve ihmal riski altında olan bebeklerin aileleri) ve adına "En İyi Başlangıçlar" denen bir toplulukla, belli bir program dâhilinde aylık edebiyat okuma çalışması yapılmıştır (26). Ayrıca aynı üniversitenin eğitim atölyelerinde sağlık bakımı veren hastanelerdeki doktorlara, hemşirelere, sosyal hizmet uzmanlarına, psikanalistlere ve terapistlere; okuma, özenli dinleme ve reflektif yazım bileşenlerini içeren kurs ve seminer eğitimleri verilmiştir. Bu atölyelerde, ikinci sınıf tıp öğrencileri için insani bilimler seminerleri, çalışanlar için seminerler, hastanede yatan hastalar ve hekimler için edebiyat seminerleri, sağlık meslek mensupları için yaratıcı yazarlık atölyeleri ve karışık klinisyen ve hasta grupları için seminerler gibi faaliyetler yapılmıştır. $\mathrm{Bu}$ uygulamalarla katılımcılar hastalarıyla olan terapötik ilişkilerinin güçlendiğini ve başkalarının bakış açılarını benimseme veya tanımlama yeteneklerinin derinleştiğini belirtmişlerdir (10).

Kanser hastalarında anlatı yeterliliklerinin ağrı yoğunluğunu azaltıp azaltmadığını ve iyileşme duygusunu geliştirip geliştirmediğini belirlemek için, yetişkin iki yüz otuz dört kanser hastasında randomize kontrollü bir çalışma yapılmıştır. Hastalara üç hafta boyunca haftada en az bir kez 20 dakika boyunca kanserin yaşamlarını nasıl etkilediği ile ilgili bir hikâye yazmaları ve haftalık olağan aldıkları tıbbi bakım için tedaviye gelmeleri istenmiştir. Alt grup analizleri sonucunda; anlatı yazılarında yüksek duygusal açıklığa sahip olan hastaların, belirgin olarak daha az ağrıya sahip olduklarını ve anlatı yazılarında daha az duygusal açıklığı olanlara göre daha yüksek iyi olma puanları olduğunu göstermiştir (27).

Oklahoma Üniversitesi'nde lisans derecesi veren Honors Koleji'nde, programda yer alan Edebiyat ve Tıp derslerinin tıp öğrencileri üzerindeki etkilerini amaçlayan bir çalışma yapılmıştır. Öğrenciler program çerçevesinde üç saatlik edebiyat dersinde, her sinıfta reflektif yazım, sınıfta tartışma ve on beş sayfalık deneyimleri ile ilgili bir seminer raporu hazırlama etkinliği ile eğitimlerini tamamlamışlar. Araştırmanın sonucunda; öğrenciler, hasta öykülerine karş1 daha duyarlı oldukları, empatik yeterliklerinin geliştiğini ve hastalarla başa çıkmaya ilişkin deneyim kazandıklarını belirtmişlerdir (8).

Kaliforniya, Georgia, Maryland, Massachusetts, Missouri, Pennsylvania, New York, Teksas ve Batı Virginia üniversitelerinde eğitim gören otuz iki asistan ile dâhili tıp uzmanlık eğitiminin bir parçası olan reflektif yazımın asistanlar üzerindeki etkisinin değerlendirildiği çalışmada ise asistanlar; yazma deneyimlerinin temel değerlerini ve önceliklerini yeniden gözden geçirmelerini teşvik ettiğini, daha fazla kişisel farkındalık yarattığını ve duygusal bir çıkış sağladığını söylemişlerdir (28).

Ülkemizde anlatı tıbbı çalışmaları incelendiğinde; literatürde bu konuyla ilgili sınırlı araştırmaya ve bir uygulama örneğine 
rastlanılmıştır. Anlatı tıbbı, 2017-2018 eğitim öğretim y1lı bahar döneminde İstanbul T1p Fakültesi 3. Sınıf tıp öğrencileri için seçmeli ders olarak uygulanmıştır. Seçmeli ders hazırlığg için Kasım-Aralık 2017'de iki grup öğretim üyesi için workshop yapılmış ve ders sadece bir dönem uygulanmıştır (29).

Ülkemizde yapılan anlatı tıbbına ilişkin sınırlı sayıdaki çalışmadan ilki, tıp alanı dışından yapılan "Edebiyat ile Tıbbın Buluştuğu Nokta: Anlatısal Tıp" adlı çalışmadır (30). Başka bir çalışma doktora tezi olarak yapılmıştır (31). $\mathrm{Bu}$ araştırma ülkemizde "Anlatı Tıbbı ve Etik" anlamında ilk olma özelliğini taşımaktadır ve araştırmada uygulanan eğitim programı, bir grup gönüllü öğrenciye sadece bir defaya mahsus uygulanmıştır. Aynı araştırmacının yaptığı başka bir çalışmada ise, kanıta dayalı tıp ile anlatı tıbbının birlikte ele alınması üzerine vurgu yapılmıştır (32):

Bilimsel bilgi zemini olmayan bir tıp uygulaması, güvenilirliğini ve yetkinliğini kaybedecektir. ... Anlatısallıktan yoksun bir tıp ise, uygulamalarının değer içeriğinin belirli bir boyutuna kör kalacaktır.

\subsection{Anlatı Tıbbına Yönelik Tartışmalar}

Literatürde anlatı tıbbı, kanıta dayalı tıp ve bilimsel/nesnel süreçler bağlamında tartışmaya açılmış, anlatı tıbbının öznel ve deneyimsel yönü eleştiri konusu yapılmıştır. Ancak karşıt savlarda, kanıta dayalı klinik karar verme ve değerlendirmenin sezgisel/ deneyimsel tarafının da olduğu bu boyutunda içerildiği belirtilmiştir. Hastalık deneyiminin anlatısallığını ve klinik yöntemin sezgisel ve öznel yönlerini kabul etmek, kanıta dayalı tıp ilkelerinin reddedilmesini gerektirmediği ileri sürülmüştür. Daha bütüncül karar süreçleri, hekimin kendi deneyimlerine, hastanın bireysel ve kültürel özelliklerine (bağlamına) ve bilimsel çalışmalarının kanıtlarına dayanan süreçler olarak çerçevelendirilmiştir (33). Her bağlamda uygulanabilecek tek bir "doğru”yu tanımlamanın genellikle imkânsız olduğunu savunan Hunter bu tartışmayı daha ileri bir noktaya götürmüştür (34).

Etik açıdan bakıldığında, hastalara ve mesleki eğitime önemli katkılar sağlayan anlatısal yazımın bazı etik problemleri de beraberinde getirebileceği unutulmamalıdır. $\mathrm{Bu}$ yazıların çoğunluğu, bir tüketim malzemesi olarak değil, tıp fakültelerinde belli bir amaca yönelik (kolaylaştırılmış grup tartışmaları gibi) eğitim alanları kapsamında kullanılmalı ve yazılar etik hassasiyet nedeniyle titizlikle korunmalıdır (22). Etik olarak, bu tür yazılar kişisel tanımlayıcı verilerin kaldırılmasını veya değiştirilmesini garanti eden "Kişisel Verileri Koruma Kanunu" düzenlemelerinin ötesine geçmeli ve şu sorular üzerinde özenle durmalıdır: Yazı hekimin kendi kendini kritik etmesini destekliyor veya yeni öğrenmelere katkı sağlıyor mu? Yoksa sadece hekimin kendi popülerliğini büyütmesi veya kendini kanıtlama amacını mı gütmektedir? Hastayla yeterince iletişim kurularak aydınlatılmış onam almak için iyi niyetle çaba gösterilmiş midir? Hastanın yayınlamayı kabul etmesi durumunda bile, hasta bu açıklamayı sonra nasıl okuyacaktır? Hastanın varsayımsal tepkisinin ötesinde, zorunlu olarak iki kişinin (veya daha fazla) birlikte oluşturduğu bir klinik öykünün bu bireylerden sadece biri tarafindan söylendiğinde sınırlamalar nelerdir? Ayrıca görünür olmayan ama hikâyeyi derinden etkileyebilen sosyo-kültürel ve sosyo-ekonomik meseleler nelerdir? (35). Tüm bu nedenlerden dolayı anlatı yazımının doğurabileceği olumsuz etkilere karşı önlem alınmalı ve mümkün olduğu kadar korunmalıdır. DasGupta bu tür çalışmalarda rehber ilke olarak "anlatı alçakgönüllülüğü” çağrısında bulunmuştur (22). 


\section{Sonuç}

Tipta ve tıp eğitiminde biyomedikal yaklaşım, sağlık bakım süreçlerinde hasta bireyin ontolojik varlığını öteleyerek, bireyi kendi hastalığının gölgesinde bırakmaktadır. Uygulamalı biyoloji haline gelen tıp eğitimine biyopsikososyal yaklaşım perspektifinden gelen tepkiler, sosyal ve insani bilimlerin tıp eğitimine entegrasyonu sonucunu doğurmuştur. Tipta insan bilimleri, bütünlüğün kaybına anlamlı bir direnç göstererek tıp eğitimine insani ve sosyokültürel bir boyutun da dâhil edilmesi noktasında önemli olmuş ve bu kapsamda ortaya çıkan uygulamalardan birisi anlatısal yeterliklerle birlikte anlatı tıbbı olmuştur.

Anlatı tıbb1, klinik pratiğin insani ve sosyokültürel duyarlıkla güçlenmesine imkân sunmaktadır. Yine anlatı tıbbi hastalarla, hekimlerin kendileriyle ve birbirleriyle yeniden ilişkilenmesinin, yakınlık oluşturmasının bir yoludur. Hekimler her gün onlarca anlatı dinler ve anlatıllar. Şimdi onları duyma zamanı.

\section{Kaynakça:}

1. Lewis, B E. Narrative Medicine and Healthcare Reform. J Med Humanit, 2011; 32:920

2. Johna, S., Rahman, S. Humanity before Science: Narrative Medicine, Clinical Practice, and Medical Education. The Permanente Journal, 2011; 15 No. 4

3. Pellegrino, ED. Humanism and the physician. Knoxville, TN: University of Tennessee Press, 1979; 127.

4. Zaner, R. Medicine and Dialogue. Journal of Medicine and Philosophy, 1990; 303.
5. Charon, R., Montello, M. Memory and anticipation: The practice of narrative ethics. In: Stories Matter: The Role of Narrative in Medical Ethics, Ed.: R. Charon, M. Montello. New York, London: Routledge, 2002. p.: ix-xii.

6. Evans, M. Medicine, philosophy, and the medical humanities. Br J Gen Pract, 2002; 447449.

7. Bleakley, A., Marshall, R., Brömer, R. Toward an Aesthetic Medicine: Developing a Core Medical Humanities Undergraduate Curriculum. J Med Humanit, 2006; 27:197-213

8. Vannatta, S., Vannatta, J. Functional Realism: A Defense of Narrative Medicine. Journal of Medicine and Philosophy, 2013; 38: 32-49.

9. Charon, R. "Narrative and Medicine," New England Journal of Medicine, 2004; 350, No. 9; 862-864.

10. Charon, R. What to do with stories The sciences of narrative medicine. Canadian Family Physician, 2007; 53

11. Charon, R. Narrative medicine in the international education of physicians. Presse Med, 2013; 42(1): 3-5.

12. Pellegrino ED. Being ill and being healed: some reflections on the grounding of medical morality. Bull N Y Acad Med, 1981; 57(1):70-9.

13. Charon, R. Narrative Medicine A Model for Empathy, Reflection, Profession, and Trust. JAMA, 2001; 286:1897-1902 
14. Brendel, W. A Framework for NarrativeDriven Transformative Learning in Medicine, Journal of Transformative Education, 2009; 7 , 26-43

15. Myrth-Kaplan, N. Interpreting people as they interpret themselves Narrative in medical anthropology and family medicine. Canadian Family Physician. 2007; 53

16. DasGupta, S., Charon, R. Personal Illness Narratives: Using Reflective Writing to Teach Empathy. Acad Med, 2004; 79:351-356.

17. Novack, DH., Suchman, AL., Clark, W., Epstein, RM., Najberg, E., Kaplan, C. Calibrating the physician: personal awareness and effective patient care. JAMA, 1997; 278:502-509.

18. Miller, SZ., Schmidt, HJ. The habit of humanism: a framework for making humanistic care a reflexive clinical skill. Acad Med, 1999; 74:800-803.

19. Alcauskas, A., Charon, R. Right Brain: Reading, writing, and reflecting: Making a case for narrative medicine in neurology. Neurology, 2008; 70;891-894

20. Charon, R. Close Reading: The Signature Method of Narrative Medicine. The Principles and Practice of Narrative Medicine, Chapter 7, Oxford University Press, 2017.

21. Charon, R. Reading, writing and doctoring: literatüre and medicine. Am J Med, 2000; 319:285-291.

22. Shapiro, J. Narrative Medicine and Narrative Writing. Family Medicine, 2012; 44(5):309-11
23. Mann, K., Gordon, J., MacLeod, A. Reflection and reflective practice in health professions education: a systematic review. Adv Health Sci Educ Theory Pract, 2009; 14(4):595621.

24. Hunter, KM. Charon, R. Coulehan, J. The study of literatüre in medical education. Acad Med. 1995; 70:787-794.

25. Charon, R. Banks, JT. Connelly, J. et al. Literature and medicine: contributions to clinical practice. Ann Intern Med. 1995; 122:599-606.

26. DasGupta, S., Meyer, D., CaleroBreckheimer, A., W. Costley, A., Guillen, S. Teaching Cultural Competency Through Narrative Medicine: Intersections of Classroom and Community. Teaching and Learning in Medicine, 2005; 18(1), 14-17

27. Soledad Cepeda, M., Chapman, C.R., Nelcy Miranda, R., Sanchez, R., Rodriguez, C.H., Restrepo, E.A., Ferrer, L.M., Linares, MD., Carr, D.B. Emotional Disclosure Through Patient Narrative May Improve Pain and WellBeing: Results of a Randomized Controlled Trial in Patients with Cancer Pain. Journal of Pain and Symptom Management, 2008; 623 Vol. 35 No. 6

28. Levine, RB., Kern, DE., Wright, SM. The impact of a prompted narrative writing during internship on reflective practice: a qualitative study. Adv Health Sci Educ Theory Pract, 2008; 13(5):723-33

29. Bahadır, G., Bıyık, F., Solakoğlu, Z., Mutlu, Ü. İstanbul Üniversitesi İstanbul Tip Fakültesinde Anlatısal Tıp (Narrative Medicine) Uygulamasi. Poster sunumu. X. Ulusal Tip 
Eğitimi Kongresi. 2018. Ege Üniversitesi, İzmir.

30. Dervişcemaloğlu, B. Edebiyat İle Tıbbın Buluştuğu Nokta: Anlatısal Tip. Yeni Türk Edebiyatı Dergisi. Dergâh Yayınları, 2012; 6

31. Kavas, M.V. "Ölüm Ve Ölmekte Olan Hastaya Yaklaşım” Konusundaki Etik Eğitiminde Anlatısal Uygulamaların Etkililiği. Ankara Üniversitesi Sağlık Bilimleri Enstitüsü. Doktora Tezi, 2008.

32. Kavas, M.V. Anlatısallık ve Tip Etiği Eğitimindeki Yeri. Ankara Üniversitesi T1p Fakültesi Mecmuası, 2011; 64 (2), 59-73.

33. Greenhalgh, T. Narrative based medicine Narrative based medicine in an evidence based World. Education and debate. BMJ, 1999; 318 34. Hunter, K. "Don't think zebras": uncertainty, interpretation, and the place of paradox in clinical education. Theor Med,1996;17:22541.

35. Peterkin, A. Primum non nocere: on accountability in narra $\neg$ tive-based medicine. Lit Med, 2011; 29(2):396-411. 